\title{
Range Plant Yield and Species Relationships in Natural and Partially Controlled
}

\section{Environments}

\author{
ALVIN T. BLEAK, WESLEY KELLER, AND A. C. HULL, JR.
}

Highlight: Competition and herbage production studies were established on soil columns (1.2 $\mathrm{m}$ square) that were isolated from the surrounding soil by heavy plastic sheeting to a depth of $1.4 \mathrm{~m}$. Some plots received only natural precipitation, some 1-1/2 times the growing-season precipitation, and some $2 / 3$ the growing-season precipitation. These different moisture levels had no significant effect on herbage yields during the 3-year period. Plots of alfalfa yielded most. Plots containing Kochia yielded as much as those containing alfalfa the first year, but not thereafter. Crested wheatgrass consistently outyielded Russian wildrye. Adjacent natural field plantings of the same species provided evidence that both alfalfa and Kochia had roots below the plastic barrier and were obtaining moisture from adjacent soil. Alfalfa was least affected and Kochia most affected by a close (5-cm) harvest height.

Authors are range scientist, agronomist, and range scientist, Agricultural Research Service, U.S. Department of Agriculture, Logan, Utah.

The research represents cooperative investigations of the Agr. Res. Serv., U.S. Dep. Agr., and the Utah Agricultural Experiment Station, Logan. (Utah Agr. Exp. Sta. Paper 1787.)

Manuscript received December 10, 1973.

Since the climate is an ever-changing variable, each crop season is different from all others. In the West, water is generally regarded as of first importance in determining plant response (Keller, 1971).

Studies on the relationship of weather to crops have emphasized the importance of precipitation and other climatic factors on production and also demonstrated the adaptability of various species or varieties to specific conditions. Annual herbage production on arid rangelands can vary by several hundred percent, generally as a result of precipitation (Hannay and Lacy, 1931).

Competition and herbage production studies were established on isolated soil plots where growing season precipitation was increased or decreased and on adjacent unaltered field plots. Selected range species were compared as single species and in mixtures for 3 years. This study was established to determine stand improvement or depletion with age, the production by single species and species mixtures, and to follow the soil moisture depletion within the isolated soil plots. 


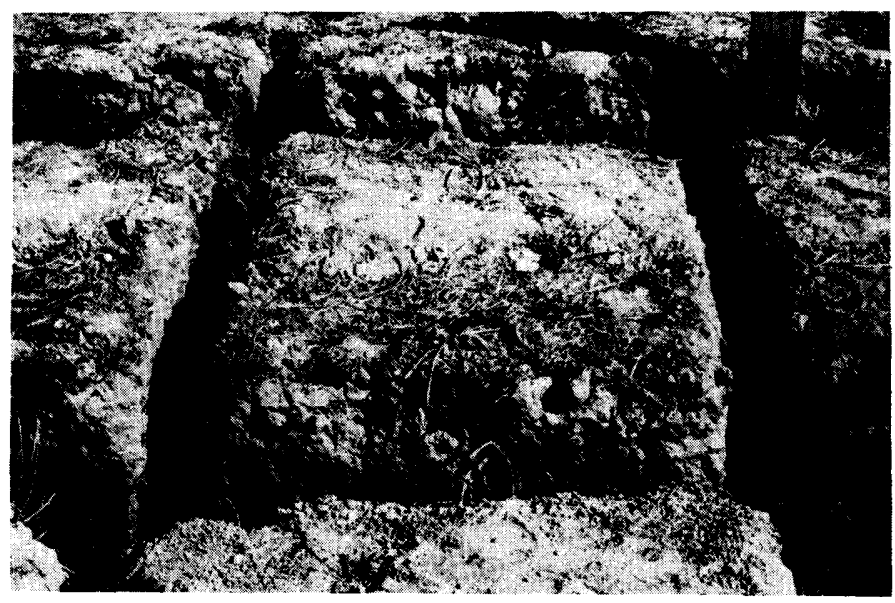

Fig. 1. Natural soil columns were separated from the surrounding soil by a sheet of plastic to a depth of $1.4 \mathrm{~m}$.

\section{Materials and Methods}

The study was located about $4 \mathrm{~km}$ northeast of Logan, Utah on dry farmland with a rather uniform slope (6.5\%). The soil was essentially free of rock to a depth of $1.4 \mathrm{~m}$. This soil was classified in the Parleys series which is a member of a fine-silty, mixed, mesic family of calcic argixerolls (U. S. Department of Agriculture, 1970).

Sixty-seven undisturbed soil columns (Fig. 1) $1.2 \mathrm{~m}$ square (4 $\mathrm{ft}$ square) were separated from the surrounding soil by a sheet of plastic to a depth of $1.4 \mathrm{~m}$. The details of the field development have been reported (Keller et al., 1974). These isolated columns were handseeded to four rows $30 \mathrm{~cm}$ apart. Good stands were produced from seedings made in the spring of 1969 by use of a portable sprinkling system. The same species or species combinations were planted under natural field conditions on either side of these isolated columns. These plantings were $2.4 \mathrm{~m}$ wide $(8 \mathrm{ft})$, with about $2 \mathrm{~m}$ of clean-cultivated land between them and the row of isolated columns.

Where two species were planted in a single plot, they were in alternate rows, except when cheatgrass (Bromus tectorum L.) was included. Cheatgrass seed was mixed with seed of 'Nordan' crested wheatgrass (Agropyron desertorum (Fisch. ex Link) Schult.) or with 'Vinall' Russian wildrye (Elmus junceus Fisch.) to determine the effect of cheatgrass competition on both the establishment and productivity of these perennial grasses. Plants were hand-clipped at about $5 \mathrm{~cm}$ above the ground. 'Ladak' alfalfa (Medicago sativa L.) and Kochia prostrata (L.) Schrad. produced enough regrowth after the initial harvest that one or two additional crops were taken each year.

Catchments (Fig. 2) were used to increase growing-season precipitation ( $11 / 2$ natural) or decrease precipitation $(2 / 3$ natural) after snow melt-usually around April 1. They were removed about October 1. Therefore only spring and summer precipitation was altered. Gypsum moisture blocks placed at six depths $(15,30,46,76,106$, and $137 \mathrm{~cm})$ in each soil column were read 9 to 12 times each year to determine the effect of moisture treatments.

\section{Results and Discussion}

\section{Effect of Adjusted Precipitation}

The mean yields of seven species or species combinations with additional water ( $11 / 2$ natural) and reduced water $(2 / 3$ natural) during the growing season are presented in Fig. 3. Generally those plots receiving two-thirds natural precipitation

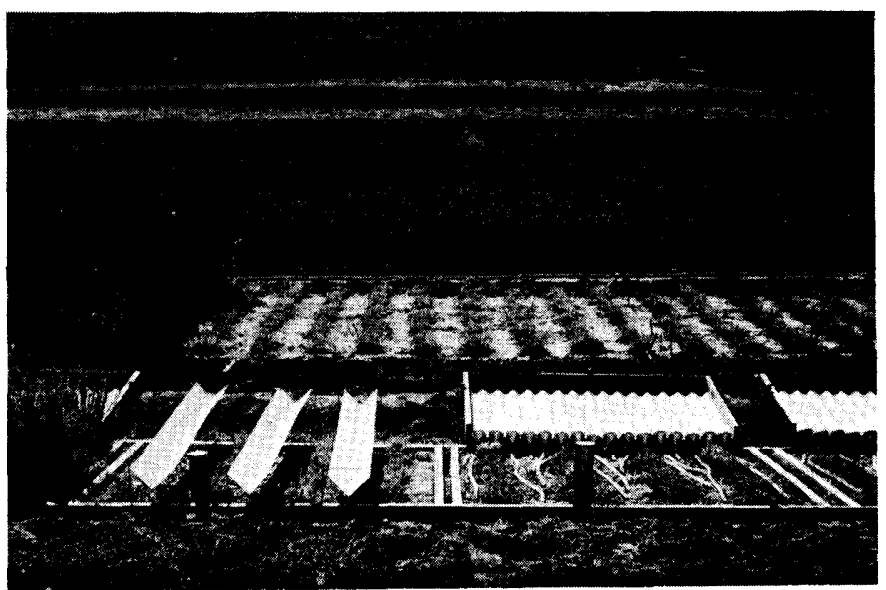

Fig. 2. The trough carried $33 \%$ of the moisture off the plot, but the catchments increased the moisture catch from each storm during the growing season by 50\%.

were drier than those receiving $11 / 2$ times natural precipitation. These two levels did not result in any significant differences in yield of individual species or species combinations. We have thereforc combined the water levels in all comparisons of species and mixture combinations.

Crop-year precipitation (Oct. to Sept.) for 1970, 1971, and 1972 was 485, 673, and $515 \mathrm{~mm}$ respectively (Table 1). Spring precipitation (April-June) before the first harvest was 159,

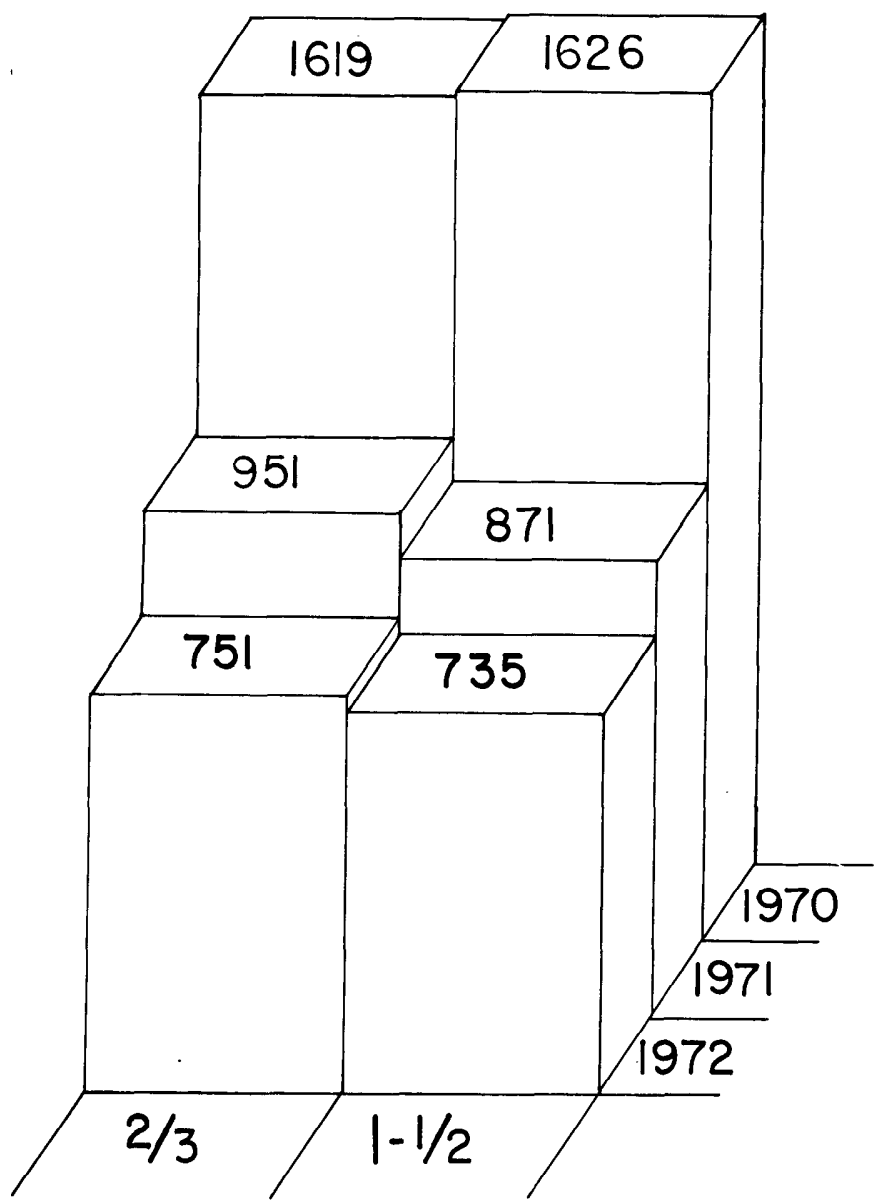

Fig. 3. Mean yield of seven species or species-combinations in three replications with reduced water (2/3 natural) or additional water (1-1/2 natural) in 3 consecutive years. 
Table 1. Precipitation (mm) at Green Canyon study area for the $\mathbf{1 9 7 0 ,}$ 1971 , and 1972 crop years. $^{1}$

\begin{tabular}{lrrr} 
Month & 1970 & 1971 & 1972 \\
\hline October & 50 & 76 & 119 \\
November & 9 & 109 & 31 \\
December & 44 & 64 & 71 \\
January & 68 & 91 & 35 \\
February & 26 & 34 & 17 \\
March & 43 & 69 & 32 \\
April & 60 & 75 & 104 \\
May & 44 & 56 & 6 \\
June & 55 & 35 & 40 \\
July & 26 & 7 & 2 \\
August & 53 & 21 & 17 \\
September & 7 & 36 & 41 \\
Total & 485 & 673 & 515 \\
\hline
\end{tabular}

${ }^{1}$ Each crop year began in October and ended in September of the year stated.

166 , and $150 \mathrm{~mm}$ for 1970,1971 , and 1972 respectively. The precipitation differences between additional ( $11 / 2$ natural) and reduced (2/3 natural) totaled 132,138 , and $125 \mathrm{~mm}$ for the April-June precipitation for 1970, 1971, and 1972. Apparently this April-June precipitation did not have much effect on first harvest yields.

\section{Soil Moisture}

The soil-moisture blocks were read nine times in 1970 between April and September, 10 times in 1971 between April and October, and 12 times in 1972 between April and October. The soil surface dried rapidly after spring snow melt and after each stormy period. Soil moisture tension at the $15-\mathrm{cm}$ depth was usually between 5 and 10 bars by mid-May providing the precipitation in a single storm did not exceed 10 $\mathrm{mm}$. Soil moisture tension at the $45-\mathrm{cm}$ depth had increased to more than 5 bars by the end of May each year. The soil depths where moisture tension remained below 1 bar up to the first harvest are shown in Table 2.

Some species combinations differed significantly with respect to depth of soil drying. Crested wheatgrass with alfalfa dried the soil most, followed by crested wheatgrass with Russian wildrye. None of the other combinations differed significantly. Only a few plots had moisture tension greater than 1 bar at the $137-\mathrm{cm}$ depth (deepest), even by the end of the summer. That soil moisture was not a limiting factor at the $137-\mathrm{cm}$ depth has an important bearing on the interpretation of our data and the behavior of alfalfa and Kochia. Information obtained from this study should apply to range sites where soil moisture is normally recharged to field capacity to a depth of about $1 \mathrm{~m}$ ( 3 feet) by late fall, winter, and early spring precipitation.

\section{Yield in the Columns Compared with Outside}

In 1970, the outside yields were greater than those in isolated columns except for plots including alfalfa or Kochia (Table 3). The greater yields of these species inside demonstrated that their roots had extended below the plastic barrier and were benefitting from the absence of competition outside. Since moisture tension exceeded $1 \mathrm{bar}$ at the $137-\mathrm{cm}$ depth only on the alfalfa plots and only in 1970 (Table 2), the above interpretation may be an oversimplification. By 1971, crested was yielding more on the isolated columns than outside, and by 1972 , Russian wildrye was also.

All harvested plots outside the columns were provided with a border extending about $1 \mathrm{~m}$ ( 3 feet) beyond the plot to approximate conditions in a large field planting. Relatively rapid growth of plants in this border from the available moisture in the surrounding bare area resulted in larger, more vigorous plants. These larger border plants continued to grow after plants within the plot had apparently depleted most of the available moisture in the root zone. The border plants apparently adversely affected plant growth, size, and yield within the plots outside the columns.

\section{Components of the Mixtures}

Three combinations of crested wheatgrass with (1) Russian wildrye, (2) alfalfa, and (3) Kochia in alternate rows provided an opportunity to assess the contribution of each species to the total plot yield (Table 4). All species yielded well during 1970 , the first harvest season. All species except alfalfa declined drastically in yield in 1971. This decline in yield in

Table 2. Soil depth $(\mathrm{cm})$ where moisture remained readily available (tension below 1 bar) under plantings of species or mixtures at first harvest each year. Adjusted precipitation was reduced to 2/3 natural or increased to 1-1/2 natural precipitation.

\begin{tabular}{|c|c|c|c|c|c|c|}
\hline \multirow[b]{2}{*}{ Species or mixtures } & \multirow{2}{*}{$\begin{array}{c}\text { Adjusted } \\
\text { precipitation }\end{array}$} & \multicolumn{3}{|c|}{ Year } & \multirow[b]{2}{*}{ Mean } & \multirow[b]{2}{*}{ Crop mean } \\
\hline & & 1970 & 1971 & 1972 & & \\
\hline Crested wheatgrass and alfalfa & $\begin{array}{r}2 / 3 \\
1-1 / 2\end{array}$ & $\begin{array}{l}137 \\
137\end{array}$ & $\begin{array}{r}97 \\
107\end{array}$ & $\begin{array}{l}107 \\
107\end{array}$ & $\begin{array}{l}113.5 \\
116.8\end{array}$ & $115.2 \mathrm{a}^{1}$ \\
\hline Crested wheatgrass and Russian wildrye & $\begin{array}{r}2 / 3 \\
1-1 / 2\end{array}$ & $\begin{array}{l}76 \\
66\end{array}$ & $\begin{array}{r}107 \\
97\end{array}$ & $\begin{array}{l}107 \\
107\end{array}$ & $\begin{array}{l}96.5 \\
89.7\end{array}$ & $93.1 \mathrm{ab}$ \\
\hline Crested wheatgrass and Kochia & $\begin{array}{r}2 / 3 \\
1-1 / 2\end{array}$ & $\begin{array}{l}97 \\
76\end{array}$ & $\begin{array}{l}76 \\
76\end{array}$ & $\begin{array}{r}107 \\
97\end{array}$ & $\begin{array}{l}93.2 \\
83.1\end{array}$ & $88.2 \mathrm{abc}$ \\
\hline Crested wheatgrass & $\begin{array}{r}2 / 3 \\
1-1 / 2\end{array}$ & $\begin{array}{r}107 \\
86\end{array}$ & $\begin{array}{l}56 \\
76\end{array}$ & $\begin{array}{r}66 \\
107\end{array}$ & $\begin{array}{l}76.2 \\
89.7\end{array}$ & $83.0 \mathrm{abc}$ \\
\hline Russian wildrye & $\begin{array}{r}2 / 3 \\
1-1 / 2\end{array}$ & $\begin{array}{l}86 \\
56\end{array}$ & $\begin{array}{l}97 \\
66\end{array}$ & $\begin{array}{l}97 \\
56\end{array}$ & $\begin{array}{l}93.2 \\
59.2\end{array}$ & $76.2 \mathrm{abc}$ \\
\hline Crested whea tgrass and cheatgrass & $\begin{array}{r}2 / 3 \\
1-1 / 2\end{array}$ & $\begin{array}{l}76 \\
41\end{array}$ & $\begin{array}{l}76 \\
86\end{array}$ & $\begin{array}{l}66 \\
36\end{array}$ & $\begin{array}{l}72.9 \\
54.1\end{array}$ & $63.5 \mathrm{bc}$ \\
\hline Russian wildrye and cheatgrass & $\begin{array}{r}2 / 3 \\
1-1 / 2\end{array}$ & $\begin{array}{l}66 \\
41\end{array}$ & $\begin{array}{l}51 \\
46\end{array}$ & $\begin{array}{l}76 \\
30\end{array}$ & $\begin{array}{l}64.3 \\
39.0\end{array}$ & $51.6 \mathrm{c}$ \\
\hline Means & $\begin{array}{r}2 / 3 \\
1-1 / 2\end{array}$ & $\begin{array}{l}92.2 \\
71.9\end{array}$ & $\begin{array}{l}79.8 \\
79.0\end{array}$ & $\begin{array}{l}89.2 \\
77.1\end{array}$ & $\begin{array}{l}87.1 \mathrm{a} \\
75.9 \mathrm{a}\end{array}$ & \\
\hline
\end{tabular}

\footnotetext{
${ }^{1}$ Three-year means followed by the same letter do not differ significantly at the $1 \%$ level.
} 
Table 3. Mean herbage yield (g) on isolated columns and on adjacent outside plots. Each value from columns for crested wheatgrass or Russian wildrye is a mean of 15 plots, and for the species combinations is a mean of six plots. Each value for outside is a mean of 30 and 12 plots, respectively.

\begin{tabular}{|c|c|c|c|c|c|c|c|c|c|}
\hline \multirow[b]{2}{*}{ Species } & \multicolumn{3}{|c|}{1970} & \multicolumn{3}{|c|}{1971} & \multicolumn{3}{|c|}{1972} \\
\hline & Columns & $\begin{array}{c}\text { Outside } \\
\text { plots }\end{array}$ & Ratio & \multicolumn{3}{|c|}{ Outside } & \multicolumn{3}{|c|}{ Outside } \\
\hline Crested wheatgrass & 1,330 & 1,393 & 0.95 & 683 & 548 & 1.25 & 430 & 263 & 1.64 \\
\hline Russian wildrye & 1,038 & 1,171 & 0.89 & 358 & 329 & 1.09 & 281 & 152 & 1.85 \\
\hline Crested and Russian wildrye & 1,587 & 1,702 & 0.93 & 593 & 506 & 1.17 & 369 & 241 & 1.53 \\
\hline Crested and alfalfa & 2,880 & 2,218 & 1.30 & 2,832 & 1,475 & 1.91 & 2,396 & $1, \overline{341}$ & 1.79 \\
\hline Crested and Kochia & 2,843 & 2,143 & 1.33 & 1,188 & 721 & 1.65 & 1,231 & 910 & 1.35 \\
\hline Crested and cheatgrass & 863 & 1,075 & 0.80 & 592 & 605 & 0.98 & 373 & 355 & 1.05 \\
\hline Russian wildrye and cheatgrass & 843 & 1,003 & 0.84 & 208 & 331 & 0.63 & 263 & 220 & 1.20 \\
\hline Mean & 1,626 & 1,529 & & 922 & 632 & & 763 & 497 & \\
\hline
\end{tabular}

1971 occurred in a high-precipitation year. Yield declined further in 1972, except with Kochia, which increased.

Mean yields by years differed greatly. The decline in yield of crested wheatgrass and Russian wildrye from 1970 to 1971 is a good indication that the severe harvesting procedure was a factor. All species appear to have suffered some damage, although alfalfa was noticeably tolerant to close harvest $(5 \mathrm{~cm})$. Kochia was damaged particularly, and after the first year was harvested at $7.5 \mathrm{~cm}$.

Although soil moisture was recharged to near field capacity each spring, mean yield declined each year except for Kochia which made some recovery in 1972 with less severe harvesting. Altering the growing-season precipitation did not significantly affect yield of perennial forage species. Crested wheatgrass showed a rather consistent decline in the three different combinations. About two-thirds of the yield from the alternate-row plots of the crested wehatgrass and Russian wildrye was crested wheatgrass. After the first year, crested wheatgrass produced only about one-fifth of the crested wheatgrass alfalfa combination, which was significantly higher in yield.

Table 4. Yield (g) and composition (\%) of Russian wildrye, alfalfa, and Kochia when each is grown in mixture with crested wheatgrass for 3 years. Yield is the mean for three replications at two moisture levels.

\begin{tabular}{|c|c|c|c|c|c|c|}
\hline \multirow[b]{2}{*}{ Mixture } & \multicolumn{2}{|c|}{1970} & \multicolumn{2}{|c|}{1971} & \multicolumn{2}{|c|}{1972} \\
\hline & Yitld & Comp. & Yield & Comp. & Yield & Comp. \\
\hline Crested wheatgrass & 1,031 & 61 & 379 & 75 & 168 & 70 \\
\hline Russian wildrye & 672 & 39 & 127 & 25 & 73 & 30 \\
\hline Total & 1,703 & 100 & 506 & 100 & 241 & 100 \\
\hline Crested wheatgrass & 979 & 44 & 277 & 19 & 260 & 19 \\
\hline Alfalfa & 1,240 & 56 & 1,198 & 81 & 1,081 & 81 \\
\hline Total & 2,219 & 100 & 1,475 & 100 & 1,341 & 100 \\
\hline Crested wheatgrass & 1,088 & 51 & 400 & 55 & 309 & 34 \\
\hline Kochia & 1,056 & 49 & 322 & 45 & 600 & 66 \\
\hline Total & 2,144 & 100 & 722 & 100 & 909 & 100 \\
\hline
\end{tabular}

About two-thirds of the yield from the alternate-row plots of the crested and Russian wildrye was crested. After the first year, crested produced only about one-fifth of the crestedalfalfa combination, which was significantly higher in yield.

Russian wildrye was clearly less productive than crested wheatgrass. In the first year, plots of crested wheatgrass and Russian wildrye planted in alternate rows exceeded the yield of plots seeded to crested wheatgrass alone. Thereafter, crested wheatgrass alone was more productive than the alternate-row mixture. In plots where crested wheatgrass or Russian wildrye seeds were mixed with cheatgrass seeds, the stand of perennial grass was poorer than where perennial grasses were seeded alone. Yields from perennial grass mixed with cheatgrass were consistently less than those where cheatgrass was not included. By the third growing season, neither of these species had recovered from the competition provided by cheatgrass where the seed mixtures were planted.

Total plot yields from a mixture of crested wheatgrass with alfalfa or Kochia were greater than production from either crested wheatgrass or Russian wildrye planted alone or mixed. The relatively deep rooted alfalfa and Kochia made good and fair regrowth respectively after harvest. The shallower rooted crested wheatgrass and Russian wildrye plants had depleted most of the available soil moisture from the upper $50-\mathrm{cm}$ depth and made little regrowth after first harvest.

\section{Literature Cited}

Hannay, A. M., and M. G. Lacy. 1931. The influence of weather on crops: 1900-1930. A selected and annotated bibliography. U.S. Dep. Agr. Misc. Pub. No. 118. 246 p.

Keller, Wesley. 1971. Limits on western range forage production-water or man. J. Range Manage. 24:243-247.

Keller, Wesley, A. T. Bleak, and A. C. Hull, Jr. 1974. Isolated soil columns for plant research: procedure and uniformity trial. Agron. J. $66: 720-722$.

U. S. Department of Agriculture. 1970. Soil taxonomy of the National Cooperative Soil Survey. U. S. Dep. Agr., Soil Conserv. Serv. Washington, D. C. 